\title{
PEMBATALAN AKTA PERJANJIAN IKATAN JUAL BELI TANAH KAVLING
}

\section{Imam Sujono ${ }^{a}$, Sugeng Irawadi ${ }^{\text {, }}$, Setiawan Indradiyasa}

aProgram Magister IImu Hukum Universitas Bhayangkara Surabaya, Indonesia bProgram Magister Ilmu Hukum Universitas Bhayangkara Surabaya, Indonesia cProgram Magister IImu Hukum Universitas Bhayangkara Surabaya, Indonesia

\section{Abstrak}

Objek pembahasan dalam Tinjauan Yuridis ini adalah Putusan Nomor : 535/Pdt.G/2015/PN.SBY dalam perkara sengketa Pembatalan Akta Perjanjian Ikatan Jual Beli No. 33 yang dibuat dihadapan Notaris Wahyudi, SH, tertanggal 15 Februari 2012 setelah Ronawati Wongso sebagai pembeli tanah kavling melunasi pembayaran atas pembelian tanah kavling kepada PT. Darmo Green Land sebagai penjual tanah kavling. Penulisan Tinjauan Yuridis putusan ini menggunakan metode penelitian hukum normatif yang berdasarkan Kepada norma yuridis hukum atas objek yang diteliti mulai duduk perkara sengketa, fakta hukum, pertimbangan majelis hakim sampai dijatuhkan putusan terhadap perkara Pembatalan Akta Perjanjian Ikatan Jual Beli. Tinjauan Yuridis ini menekankan bahwa salah satu tugas utama pengadilan yaitu membuat putusan atas sebuah perselisihan yang memberi kemanfaatan terhadap kedua pihak yang berselisih. Putusan yang dijatuhkan idealnya dapat memberikan kemanfaatan secara positif, agar putusan yang dibuat oleh pengadilan mampu menjadi sebuah putusan yang berwibawa dan bijaksana. Hasil penelitian menunjukkan bahwa majelis hakim sangat cermat dan berhati-hati dalam mengambil pertimbangan hukum. Sehingga, putusannya mencerminkan keadilan dan bersesuaian dengan norma hukum yang ada..

Kata Kunci: Akta Perjanjian; Jual Beli Tanah Kavling; Ikatan Jual Beli; Pembatalan Perjanjian.

\begin{abstract}
The object of discussion in this Juridical Review is Decision Number: 535 / Pdt.G / 2015 / PN.SBY in the case of dispute Cancellation of Purchase Agreement No. 33 that was made in front of Wahyudi, SH, as Notary dated February 15, 2012 after Ronawati Wongso as the buyer of land plots settled payment for the purchase of land plots to PT. Darmo Green Land as a seller of land plots. Writing the Judicial Review this ruling uses the method of normative legal research based on the legal juridical norms of the object under study, starting to sit on disputes, legal facts, judges' deliberations until a verdict is handed down on the case of cancellation of the Deed of Sale Agreement. This Juridical Review emphasizes that one of the main tasks of the court is to make a decision on a dispute that benefits both parties. Decisions handed down should ideally be of positive benefit, so that decisions made by the court are capable of being authoritative and wise. The results showed that the panel of judges was very careful and careful in taking legal considerations. Thus, the decision reflects justice and is in accordance with existing legal norms
\end{abstract}

Keywords: Cancellation of Purchase Agreement, Legal Research, Decision, Legal Norms, Penulis : ${ }^{a}$ imamsujono.shi@gmail.com 


\section{LATAR BELAKANG}

Pengadilan menjadi sebuah instansi pemerintah yang dipercaya masyarakat sebagai tempat meletakkan harapan untuk mendapatkan keadilan atas masalah hukum yang mereka alami. Banyak dari para pencari keadilan percaya bahwa mereka akan mendapatkan apa yang mereka harapkan dari lembaga peradilan, untuk harapan tersebut sudah sewajarnya seluruh stakeholder lembaga peradilan bekerja secara extraordinary.

Produk hukum lembaga peradilan ada dua yaitu penetapan dan putusan. Penetapan merupakan keputusan pengadilan yang dihasilkan atas permohonan dan putusan merupakan keputusan pengadilan atas perkara gugatan berdasarkan adanya suatu sengketa atau perselisihan yang berisi penyelesaian final atas persengketaan perkara. Berdasarkan hal ini pengadilan menentukan dengan pasti hak ataupun hubungan hukum terhadap objek sengketa bagi para pihak.

Peradilan sebagai ujung tombak penegakan hukum diharapkan dapat memberikan rasa keadilan kepada masyarakat. Hasil kerja lembaga peradilan melalui penjatuhan putusan yang bertitik tolak pada nilai-nilai keadilan, berdasarkan Ketuhanan Yang Maha Esa menjadikan pengadilan sebagai barometer sekaligus legitimasi masyarakat dalam menilai dari institusi yudisial.

Dalam menjalankan fungsinya untuk menegakkan keadilan, maka peradilan memerlukan dasar norma hukum dan perundang - undangan dalam menjatuhkan putusan. Dasar norma hukum tersebut salah satunya berupa KUHPerdata, sehingga pengadilan harus memutuskan permasalahan tersebut untuk menjamin kepastian hukum.

Pada tanggal 15 Februari 2012, PT. Darmo Green Land pada saat itu diwakili oleh direktur yang bernama Sukanto Tjakra dan Ronawati Wongso membuat perjanjian jual beli dihadapan Notaris Wahyudi, SH di Surabaya, sebagaimana tertulis dalam Akta Perjanjian Ikatan Jual Beli Nomor 33, tertanggal 15 Februari 2012 atas 2 bidang tanah HGB No. 715/Kel Sukomanunggal, seluas $375 \mathrm{M}^{2}$ dan tanah HGB No. 716/Kel Sukomanunggal, seluas $375 \mathrm{M}^{2}$ dengan total harga Tiga Milyar Tiga Ratus Juta Rupiah (Rp. 3.300.000.000,-) dengan peralihan hak atas tanah setelah pembayaran dilakukan lunas.

Sesuai dengan perjanjian yang telah disepakti maka setelah lunas melakukan pembayaran Ronawati Wongso menerima Sertipikat HGB No. 715 dan Sertipikat HGB No. 716 sebagaimana dalam TandaTerima tanggal 23 Januari 2013 dari PT. Darmo Green Land yang diwakili oleh Soekanto Tjakra yang sudah tidak menjabat sebagai direktur.

Setelah terjadi perubahan pengurus PT. Darmo Green Land menyadari bahwa Perjanjian Ikatan Jual Beli yang dilakukannya dengan Ronawati Wongso bertentangan dengan perundang-undangan yang yang berlaku, yaitu: Pasal 146 ayat (1) UU No. 1 Tahun 2011 tentang Perumahan dan Kawasan Pemukiman yang menyatakan "Badan Hukum yang membangun lisiba dilarang menjual kaveling tanah matang tanpa rumah." Jika rumusan Pasal 146 ayat (1) tersebut dihubungkan dengan fakta dalam Akta Perjanjian Ikatan Jual Beli Nomor 33, tertanggal 15 Februari 2012 yang dibuat dihadapan Notaris Wahyudi,SH maka ditemukan beberapa hal berikut:

1. Bahwa dalam Perjanjian Jual Beli antara PT. Darmo Green Land dengan Ronawati Wongso yang diperjualkan adalah tanah kavling tanpa rumah

2. Bahwa Perjanjian Jual Beli yang dilakukan oleh PT. Darmo Green Land dengan Ronawati Wongso dilakukan pada saat kondisi tidak terjadi krisis yang menyebabkan kesulitan liquiditas bagi PT. Darmo Green Land 
PT. Darmo Green Land menyadari peralihan hak atas tanah kavling yang dilakukan kepada Ronawati Wongsi melanggar perundang-undangan kemudian menawarkan kepada Ronawati Wongso untuk mengambil mengambil uang :

1. Pengembalian uang pembayaran atas pembelian tanah kavling sebesar Rp. 3.300.000.000,- (Tiga milyar tiga ratus juta rupiah)

2. Pemberian bunga $6 \%$ (Enam persen) pertahun atau $0,5 \%$ (setengah persen) perbulan, kepada Ronawati Wongso terhitung mulai lunasnya pembayaran yaitu tanggal 23 Januari 2013 hingga tanggal 16 Juni 2015.

3. PT. Darmo Green Land menawarkan kepada Ronawati Wongso untuk mengembalikan uang pembayaran yang telah dibayarkan senilai Rp. 3.300.000.000,(Tiga milyar tiga ratus juta rupiah) ditambah bunga sebesar Rp. 478.500.000,- (Empat ratus tujuh puluh delapan juta lima ratus ribu rupiah) dengan nilai total sebesar Rp. 3.778.000,- (Tiga Milyar Tujuh Ratus Tujuh Puluh Delapan Juta Lima Ratus Ribu Rupiah)

Dengan tidak tercapaianya kesepakatan antara PT. Darmo Green Land dengan Ronawati Wongso maka PT. Darmo Green Land mengajukan gugatan pembatalan Akta Perjanjian Ikatan Jual - Beli No. 33, tertanggal 15 Februari 2012 yang dibuat dihadapan Notaris Wahyudi,SH. kepada Pengadilan Negeri Surabaya.

Objek yang penulis kaji dalam Tinjauan Yuridis ilmiah ini adalah produk hukum yang dihasilkan oleh pengadilan yang berupa putusan, karena di dalam putusan tersebut penulis menemukan beberapa permasalahan yang harus diselesaikan menurut hukum, sehingga cita hukum yang diharapkan dan dinyatakan dalam konsep rechstaat atau negara hukum dapat berjalan dengan optimal. Dalam Tinjauan Yuridis ilmiah ini penulis akan mengkaji putusan yang dikeluarkan oleh Pengadilan Negeri Surabaya pada tanggal 08 Desember 2015 yaitu Putusan Nomor : 535/Pdt.G/2015/PN.SBY, mengenai sengketa jual beli tanah kavling antara PT. Darmo Green Land dan Ronawati Wongso.

\section{PERMASALAHAN}

Berawal dari latar yang sudah diuraikan tersebut penulis mengidentifikasi ada 2 permasalahan yang memerlukan jawaban atau penjelasan, yaitu:

1. Bagaimanakah isi pertimbangan dan amar Putusan Nomor : 535/Pdt.G/2015/PN.SBY?

2. Bagaimanakah tinjauan yuridis atas Putusan Nomor : 535/Pdt.G/2015/PN.SBY?

\section{METODE PENELITIAN}

Metode penelitian yang digunakan dalam penelitian ini adalah Penelitian Hukum Normatif. Bahan hukum yang dipergunakan dalam penelitian ini adalah bahan - bahan hukum (legal materialls) dikategorikan sebagai bahan hukum primer dan bahan hukum sekunder. Bahan hukum primer meliputi perundang - undangan (KUH Perdata, Undang - Undang Nomor 48 Tahunn 2009 Tentang Kekuasaan Kehakiman, UU No. 1 Tahun 2011 Tentang Perumahan dan Kawasan Pemukiman) Putusan Pengadilan Negeri Surabaya Nomor : 535/Pdt.G/2015/PN.SBY, dan Putusan Mahkamah Agung Nomor : 1673 K/Pdt/2017. Sedangkan bahan hukum sekunder meliputi berbagai karya ilmiah para ilmuwan, laporan penelitian, kamus, ensiklopedia, jurnal - jurnal penelitian hukum dan non hukum, hasil seminar, makalah, artikel maupun pendapat pakar hukum yang berkaitan dengan materi penelitian, majalah, dan lain sebagainya. 


\section{PEMBAHASAN}

\section{Pertimbangan Dan Amar Putusan Pengadilan Nomor : 535/Pdt.G/2015/PN.SBY}

Hakim menurut Komisi Hukum Nasional Republik Indonesia adalah sebuah personifikasi suatu lembaga peradilan yang agung, mempunyai tugas dan tanggung jawab dalam mengemban amanah yang berat. Didalam menentukan suatu keputusan hakim selain harus mempunyai kemampuan inteketual, hakim juga diharapkan memiliki integritas dan moral yang tinggi, bahkan pada titik tertentu, termasuk juga marus memiliki tingkat keimanan dan ketaqwaan, serta kemampuan berkomunikasi dengan bagus, sehingga dalam menjalankan perannya, kewibawaan dan statusnya dihadapan masyarakat harus dapat diperlihatkan, pada akhirnya hasil kerjanya dapat mencerminkan rasa keadilan, menjamin kepastian hukum dan dapat memberikan manfaat bagi masyarakat. ${ }^{1}$

\section{Pertimbangan Majelis Hakim :}

1. Menimbang bahwa Ronawati Wongso telah melunasi angsuran keseluruhan kepada PT. Darmo Green Land dengan total pembayaran Rp.3.300.000.000,00-

2. Menimbang bahwa PT. Darmo Green Land melalui Soekamto Tjakra selaku Direktur yang lama telah menyerahkan 2 (dua) Sertifikat HGB No.715 dan Sertifikat HGB No.716;

3. Menimbang bahwa Ronawati Wongso telah membayar lunas harga tanah dan telah diserah terimakan Sertifikat HGB yaitu pada 14 Januari 2013, maka jelaslah pada ssat intu telah terjadi jual beli tanah kavling meskipun belum terjadi penandaanganan akta jual beli;

4. Menimbang bahwa Badan Hukum yang membangun Lisiba dilarang menjual kavling Tanah matang tanpa rumah berdasarkan ketentuan pasal 146 ayat (1) UU No. 1 Tahun 2001 ;

5. Menimbang bahwa adanya ancaman sanksi pidana denda Rp.5.000.000.000,00 (lima milyar rupiah) terkait ketentuan pasal 146 ayat (1) UU No. 1 Tahun 2001 diatur dalam pasal 162 ayat (1) huruf c maka PT. Darmo Green Land sudah tepat untuk berusaha meminimalisir resiko denda tersebut dengan mengajukan pembatalan Akta Perjanjian Perikatan Jual Beli Nomor 33 yang dibuat dihadapan notaris tersebut;

6. Menimbang bahwa pasal 146 ayat (1) UU No.1 Tahun 2001 berlaku bagi perjanjian antara PT. Darmo Green Land dan Ronawati Wongso oleh karenanya perjanjian antara PT. Darmo Green Land dan Ronawati Wongso telah tidak memenuhi salah satu syarat sahnya perjanjian yakni suatu sebab yang halal karena perjanjian tersebut

\footnotetext{
${ }^{1}$ Komisi Hukum Nasional Republik Indonesia.(2003) Laporan Akhir Rekrutmen Dan Karir Di Bidang Peradilan, Disusun Oleh Kelompok Kerja A.2 Fakultas Hukum Universitas Gadjah Mada, Yogjakarta: Fakultas Hukum UGM, iii
} 
dilarang oleh Undang-Undang, berdasarkan pertimbangan-pertimbangan tersebut di atas maka perjanjian jual beli tanah tersebut haruslah dinyatakan batal demi hukum;

7. Menimbang bahwa PT. Darmo Green Land dan Ronawati Wongso telah menjalankan keawjiban masing-masing maka wajar jika keadaan dikembalikan seperti semua,dan PT. Darmo Green Land cukup adil dihukum mengembalikan semua pembayaran yang telah dilakukan Ronawati Wongso beserta bunga 1\% dengan rincian :

a. Pembayaran lunas Ronawati Wongso Rp. 3.300.000.000,-

b. Pembebanan bunga sebesar $1 \%$ x 25 Bulan = Rp. 825.000.000,-

c. Pengembalian Total PT. Darmo Green land ke Ronawati Wongso sebesar Rp. 4.125.000.000,-

8. Menimbang bahwa PT. Darmo Green Land telah mampu membuktikan dalil gugatannya sebagian maka gugatan PT. Darmo Green Land untuk bagian tersebut dapatlah dikabulkan;

Amar Putusan :

1. Mengabulkan gugatan PT. Darmo Green Land sebagian;

2. Menyatakan Akta Perjanjian Ikatan Jual Beli No.33 tertanggal 15 Pebruari 2012 yang dibuat dihadapan Notaris Wahyudi,SH, di Surabaya batal demi hukum, tidak sah dan tidak memiliki kekuatan hukum mengikat;

3. Memerintahkan PT. Darmo Green Land untuk mengembalikan uang pembayaran disertai bunga yang totalnya Rp.4.125.000.000,- (empat milyar seratus dua puluh lima juta rupiah);

4. Menolak gugatan PT. Darmo Green Land selain dan selebihnya;

5. Menghukum Ronawati Wongso untuk membayar biaya perkara sejumlah Rp.1.276.000,- (satu juta dua ratus tujuh puluh enam ribu rupiah);

Dalam memecahkan perkara semestinya hakim menekankan pada kegunaan ilmu hukum secara empiris. Hal ini mengingat bahwa ilmu hukum setidaktidaknya adalah untuk dapat menjelaskan eksistensi objeknya beserta problematik yang berkenaan dengan objeknya. Inilah kegunaan minimum ilmu yang menjadi titik pangkal bagi kegunaan manusia sesuai kepentingan dan tujuannya. Jika misalnya sudah jelas apa yang menjadi problematik dari objek ilmu tertentu yang merugikan manusia atau yang tidak menyenangkan manusia, maka pemecahannya ditentukan lagi oleh hal lain, yaitu yang sangat menentukan adalah energi yang tersedia yang dapat dipergunakan oleh manusia untuk mengatasi atau memecahkan masalah yang tidak menyenangkan manusia itu. ${ }^{2}$

\footnotetext{
${ }^{2}$ Voll, W.D.S. Negara Hukum Dalam Keadaan Pengecualian. Jakarta: Sinar Grafika, 2013, hlm.8
} 
Dalam pandangan penulis, majelis hakim dalam menjatuhkan perkara a quo lebih menekankan pada aliran positivisme yang cenderung pada pemenuhan atas kepastian hukum. Secara harfiah memang fungsi dari hukum tidak hanya menegakkan keadilan, dan ada fungsi lain yaitu kepastian sebagaimana yang digunakan. Akan tetapi jika dalam praktik ketiga fungsi hukum itu bertentangan, maka hakim dalam membuat putusan harus membuat mengutamakan keadilan di atas kepastian dan kemanfaatan dengan susunan skala prioritas yang tepat. Keadilan dijadikan pisau analisis dalam setiap tahapan putusan yang akan dibuat dalam perkara, mulai dari tahapan konstantir, tahap kualifikasi, dan tahap konstituir.

Secara konseptual, Rahardjo merumuskan pengertian penegak hukum sebagai suatu proses untuk mewujudkan keinginan-keinginan hukum menjadi kenyataan secara realitas. Keinginan hukum dalam pengertian adalah pikiran-pikiran yang menjadi pembentuk dan perumus peraturan hukum itu. Peraturan-peraturan hukum yang dibuat oleh lembaga legislatif pada dasarnya merupakan manifestasi hasil perjuangan kekuasaan di dalam masyarakat, sehingga tidaklah berlebihan jika ada pendapat bahwa pihak yang berkuasa juga menentukan bagaimana isi peraturan hukum yang dibuat). ${ }^{3}$.

Penjatuhan putusan yang hanya mendasarkan peratuan hukum yang berlaku, tanpa mempertimbangkan hasil konkret yang penerapan putusan di masyarakat dapat dikatakan bahwa putusan yang dikeluarkan telah mencederai rasa keadilan di masyarakat dan tentunya akan mempengaruhi terhadap ketertiban masyarakat hukum yang diwajibkan untuk senantiasa tunduk dan patuh terhadap segala produk hukum yang berlaku.

\section{Tinjauan Yuridis Putusan Nomor : 535/Pdt.G/2015/PN.SBY}

Menurut R. Soeparmono, sumber hukum yang dapat diterapkan oleh hakim dapat berupa peraturan perundang-undangan berikut peraturan pelaksanaannya, hokum tidak tertulis (hukum adat), putusan desa, yurisprudensi, ilmu pengetahuan maupun doktrin/ajaran para ahli. Hakim dalam memutuskan suatu perkara harus didasarkan pada berbagai pertimbangan yang dapat diterima semua pihak dan tidak menyimpang dari kaidah-kaidah hukum yang ada. Dasar hukum diartikan sebagai pencarian alasan tentang hukum atau pencarian dasar tentang bagaimana seorang hakim memutuskan perkara/kasus hukum, seorang pengacara mengargumentasi-kan hukum dan bagaimana seorang ahli hukum menalar hukum. ${ }^{4}$

3 Sujono, A.R., \& Daniel, B. (2013). Komentar Dan Pembahasan Undang-Undang Nomor 35 Tahun 2009 Tentang Narkotika. Jakarta: Sinar Grafika, 2013, hlm. 61-62

4 Tim Peneliti Komisi Yudisial RI. Profesionalisme Hakim: Studi Tentang Putusan Pengadilan Tingkat Pertama dalam Perkara Perdata dan Pidana di Indonesia. Riset: Komisi Yudisial. Jakarta, 2009. hlm 27 
Dalam menemukan hukum, ditegaskan dalam Pasal 28 UU No. 4 Tahun 2004, bahwa "Hakim wajib menggali, mengikuti dan memahami nilai-nilai hukum dan rasa keadilan yang hidup dalam masyarakat. Kata menggali mengasumsikan bahwa hukumnya itu ada, tetapi tersembunyi, agar sampai pada permukaan masih harus digali. Jadi hukumnya itu ada, tetapi masih harus digali, dicari dan diketemukan, kemudian diciptakan. Proses-proses pembuatan putusan yang selalu terkait dengan aktivitas bernalar hakim. Aktivitas bernalar dari Hakim dengan yang selalu diwarnai dengan keanekaragaman kerangka berpikir yuridis dan orientasi yang terpelihara dalam sebuah sistem autopoesis, sehingga dapat berkembang menurut logikanya sendiri, dan eksis sebagai sebuah model penalaran yang khas sesuai dengan tugas-tugas profesionalnya. ${ }^{5}$

Pada hakikatnya asas-asas tersebut terdapat dalam Pasal 178 HIR/189 RBG dan Pasal 50 UU No. 48 Tahun 2009 Tentang Kekuasaan Kehakiman, diantaranya yaitu Memuat Dasar Alasan yang Jelas dan Rinci ${ }^{6}$

Putusan yang dibuat oleh hakim harus berdasarkan pertimbangan yang jelas dan cukup sehingga dapat dipertanggungjawabkan. Putusan yang tidak memenuhi ketentuan tersebut dikategorikan putusan yang tidak cukup pertimbangan atau onvoldoende gemotiveerd. Alasan ataupun argumen yang dijadikan pertimbangan hakim dapat berupa pasal-pasal tertentu peraturan perundang-undangan, norma yang berlaku di masyarakat, hukum kebiasaan, yurisprudensi atau doktrin hukum lain.

Pasal 50 Undang - Undang No. 48 Tahun 2009 Tentang Kekuasaan Kehakiman yang menegaskan bahwasanya Putusan pengadilan selain harus memuat alasan atau argumen hukum dan dasar putusan, juga memuat pasal tertentu dari peraturan perundang-undangan yang bersangkutan atau sumber hukum tak tertulis dalam masyarakat yang dijadikan dasar untuk mengadili. ${ }^{7}$ Untuk memenuhi kewajiban itulah Pasal 5 UU Kekuasan Kehakiman memerintahkan hakim untuk menggali nilai-nilai, mengikuti, dan memahami nilai-nilai hukum dan rasa keadilan yang hidup dalam masyarakat.

Bertitik tolak dari pasal yang dikemukakan di atas, putusan yang tidak cukup pertimbangan adalah masalah yuridis, akibatnya putusan dapat dibatalkan pada tingkat banding atau kasasi. Begitu pula pertimbangan yang mengandung kontradiksi, yang pada akhirnya putusan demikian tidak memenuhi syarat sebagai putusan yang jelas dan rinci karena pertimbangan hakim yang mengandung kontradiksi tersebut, sehingga cukup alasan menyatakan putusan yang dijatuhkan

\footnotetext{
${ }^{5}$ Sidharta. Penalaran Hukum dalam Sudut Pandang Keluarga Sistem Hukum dan Penstudi Hukum, Bandung: Citra Aditya Bakti, 2000, hlm 206

6 Isnantiana, Nur Iftitah. "Legal Reasoning Hakim dalam Pengambilan Putusan Perkara di Pengadilan". Islamadina: Jurnal Pemikiran Islam, [S.I.], p. 41-56, Oct. 2017

${ }^{7}$ Undang - Undang Republik Indonesia Nomor 48 Tahun 2009 Tentang Kekuasaan Kehakiman
} 
melanggar asas yang digariskan Pasal 50 UU No. 48 Tahun 2009 Tentang Kekuasaan Kehakiman

Menurut Aristoteles terdapat dua macam keadilan, yaitu keadilan distributif (keadilan yang bersifat menyalurkan), artinya keadilan yang memberikan kepada setiap orang menurut jasa (according to merit). Keadilan ini bersifat proporsional, berarti persamaan dalam rasio (for proportion is equality of rations). Walaupun nyatanya orang menerima sejumlah yang tidak sama, tetapi dalam nalar ada persamaan, sebab penyaluran yaitu dilakukan berdasarkan jasa masing-masing. Keadilan ini tidak menuntut supaya tiap-tiap orang mendapat bagian sama banyaknya, jadi bukan persamaan melainkan kesebandingan. Keadilan distributif ini terutama menguasai hubungan antara masyarakat, khususnya negara dan individu.

Keadilan kumulatif, menurut istilah Apeldoorn atau yang oleh Aristoteles dinamakan keadilan yang bersifat membetulkan (rectiflcatory justice), yaitu keadilan yang memberikan kepada setiap orang sama banyaknya dengan tidak mengingat jasa-jasa perorangan. Keadilan ini memegang peran dalam tukar menukar, di mana dalam pertukaran barang-barang dan jasa, sebanyak mungkin harus terdapat persamaan antara apa yang dipertukarkan. Keadilan kumulatif terutama menguasai hubungan antar individu. ${ }^{8}$

Keadilan menurut Rawls pada dasarnya adalah keadilan yang mengutamakan kebebasan individual yang bertanggung jawab. ${ }^{9}$ Penegakan hukum yang adil atau berkeadilan akan tercapai apabila hukum yang ditegakkan, begitu pula hukum yang mengatur cara-cara penegakan hukum adalah benar dan berkeadilan. Suatu aturan hukum akan benar dan adil apabila dibuat dengan cara-cara yang benar dan materi muatannya sesuai dengan kesadaran hukum dan memberi sebesar-besarnya manfaat bagi kepentingan orang perorangan dan masyarakat banyak pada umumnya.

Putusan pengadilan harus dapat memberikan keadilan atau setidaknya memberikan penyelesaian sengketa yang bermanfaat kepada para pihak. Aktualisasi hakim dalam menjalankan fungsinya harus selalu mencerminkan diri pada kenyataan hukum dan norma - norma lain yang berkembang di masyarakat. Dengan menempatkan diri secara berani tapi profesional serta humanis dari cara berpikir. Penempatan asas dan teori hukum, analitis positivistik untuk meraih tujuan berupa perwujudan keadilan yang substantif tanpa meninggalkan penafsiran yang disandarkan pada harmonisasi logika dan norma hukum yang bersumber pada asas hukum lebih dari satu cabang kekhususan disiplin ilmu dalam menjatuhkan suatu putusan.

${ }^{8}$ Rumokoy, D.A., \& Maramis, F., Pengantar Ilmu Hukum, Jakarta: PT Raja Grafindo, 2014. hlm.2930

9 Akub, M.S., \& Badaru, B. Wawasan due process of law dalam sistem peradilan pidana, Yogyakarta: Rangkang Education, 2012, hlm. 19 
Dengan demikian, sudah menjadi keharusan untuk menggunakan kemapuan berpikir secara mendalam dalam rangka mencari dan menemukan hakikat kebenaran terhadapa permasahan yang terjadi merupakan sebuah jalan keluar yang rasional dengan menguunakan hukum sebagai piranti untuk mewujudkan sebuah keadilan.

Hal yang harus dilakukan oleh hakim adalah memahami esensi hermeneutika hukum dengan menginterpretasikan teks hukum, konteks bagaimana hukum itu dilahirkan, serta bagaimana kontekstualisasi atau penerapan hukumnya pada masa sekarang dan masa mendatang.$^{10}$

Di dalam hukum Indonesia yang menganut civil law system, ratio decidendi tersebut dapat dilihat pada konsiderans "Menimbang" pada "Pokok Perkara". Ratio dapat ditemukan dengan memperhatikan fakta materiil dan putusan yang didasarkan atas fakta itu. Pertimbangan hakim yang digunakan dalam memutus perkara menjadi alasan hukum atau decidendi dalam sebuah putusan pengadilan. ${ }^{11}$ Untuk menemukan ratio decidendi dalam suatu putusan biasanya dapat dilihat pada bagianbagian tertentu. Untuk sampai kepada salah satu putusan itu hakim harus menuliskan alasan-alasannya, yaitu ratio decidendinya. Dengan demikian, dari suatu fakta materiil dapat terjadi dua kemungkinan putusan yang saling berlawanan. Yang menentukan adalah Ratio decidendi putusan itu. ${ }^{12}$

Pada umumnya fungsi Legal Reasoning adalah sebagai sarana mempresentasikan pokok-pokok pemikiran tentang problematika konflik hukum antara seseorang dengan seorang lainnya, atau antara masyarakat dengan pemerintah terhadap kasus-kasus yang menjadi kontroversi atau kontraproduktif untuk menjadi replica dan duplica percontohan terutama menyangkut baik dan buruknya system penerapan dan penegakan hukum, sikap tindak aparatur hukum dan lembaga peradilan. ${ }^{13}$

Dasar hukum dari pada putusan itu harus dicantumkan dengan jelas dalam pertimbangan hukumnya, dan sesuai dengan sistem penalaran hukum dalam membuat putusan. ${ }^{14}$ Hakim dalam membuat argumentasi pada putusannya senantiasa akan menggunakan logika formal dengan menarik kesimpulan dari premis mayor dan premis minor. Selain menarik fakta atau peristiwa hukum hakim harus mensinerjikan norma-norma hukum yang berlaku dalam masyarakat,

${ }^{10}$ Rifai, A. Penemuan Hukum Oleh Hakim Dalam Perspektif Hukum Progresif. Cetakan Kedua. Jakarta: Sinar Grafika, 2011, hlm. 89

${ }^{11}$ Mertokusumo, Soedikno. Hukum Acara Perdata Indonesia, Yogyakarta: Liberty, 2002. HIm 203

12 Peter, Mahmud Marzuki. Pengantar Ilmu Hukum. Jakarta: Kencana, 2009. hlm 94

${ }^{13}$ Abraham, Amos HF. Legal Opinion Teoritis \& Empirisme. Jakarta: PT. Grafindo Persada, 2007. hlm 34

${ }^{14}$ N.E. Algra, K. van Duyvendijk, terjemah J.C.T. Simorangkir. Mula Hukum, Beberapa Bab Mengenai Hukum dan IImu Hukum untuk Pendidikan Hukum dalam Pengantar Ilmu Hukum, Jakarta: Bina Cipta, 1983. hlm 65 
baik dari hukum positif, hukum kebiasaan dan norma-norma hukum lainnya. Sehingga putusan tersebut akan terjadi sistimatis dan logis dan apabila di baca dapat diketahui atau dipahami dengan jelas argumen-argumen atau alasanalasannya. Sehingga dapat diketahui dan dipahami dari putusan tersebut mengandung kemanfaatan, kepastian hukum dan keadilan bagi pencari keadilan.

Latar belakang pembatalan akta jual beli tanah dari segi perundang-undangan dapat digolongkan : ${ }^{15}$

a. Tidak terpenihi syarat yang sudah ditetapkan oleh UU tentang perjanjian formil sehingga perjanjian batal demi hukum;

b. Tidak terpenuhinya syarat sah suatu perjanjian;

c. Terpenuhinya syarat batalnya suatu perjanjian yang bersyarat;

d. Pembatalan perjanjian yang diajukan atas dasar action paulina;

Sedangkan dalam beberapa Yurisprudensi Mahkamah Agung, ada beberapa faktor yang melatarbelakangi pembatalan akta perjanjian yang dibuat oleh PPAT, yaitu: ${ }^{16}$

a. Batalnya perjanjian karena tidak terpenuhi syarat sahnya perjanjian tentang adanya kesepakatan para pihak, sebagaimana diatur dalam pasal $1320 \mathrm{KUH}$ Perdata;

b. Batalnya perjanjian karena tidak terpenuhi syarat sahnya perjanjian tentang adanya suatu hal tertentu, sebagaimana diatur dalam pasal 1320 KUH Perdata;

c. Batalnya perjanjian karena tidak terpenuhi syarat sahnya perjanjian tentang adanya sebab yang halal, sebagaimana diatur dalam pasal 1320 KUH Perdata;

d. Batalnya perjanjian karena hak membeli kembali terhadap objek jual beli;

e. Batalnya perjanjian karena penggunaan surat kuasa mutlak dalam jaul beli;

f. Batalnya perjanjian karena bersama yang dijualbelikan;

g. Batalnya perjanjian karena syarat kebatalan dalam perjanjian jual beli;

h. Batalnya perjanjian karena kondisi keadaan darurat (noodtoestand);

i. Batalnya perjanjian karena kebatalan hak atas tanah.

Pembatalan perjanjian jual beli di hadapan Notaris mempunyai akibat hukum ganti kerugian, pebatalan perjanjian, pembatalan perjanjian disertai ganti rugi sebagaimana dinyatakan dalam Pasal 1243 dan Pasal 1244 KUH Perdata, Tuntutan gantu rugi dapat disampaikan oleh pihak yang dirugikan kepada pihak yang membatalkan perjanjian atau pihak yang telahingkar janji/wanprestasi dalam perjanjian pengikatan jual beli. ${ }^{17}$

${ }^{15}$ Rafiq Adi Wardana, Dkk. "Pembatalan Akta Jual Beli PPAT Yang Cacat Hukum Dengan Putusan Pengadilan (Studi Kasus Putusan Pengadilan Tinggi Tanjungkarang No. 17/Pdt.G/2012/PT. TK)". REPERTORIUM Vol 6, No 1 (2019)

16 Ibid

17 Fatmawati, "Kajian Yuridis Pembatalan Akta Pengikatan Jual Beli Tanah Terkait Syarat Subyektif", REPERTORIUM Vol 6, No 1 (2019) 
Adapun Perjanjian Pengikatan Jual Beli (PPJB) untuk properti rumah susun dengan sistem Pre Project Selling yang dibuat di hadapan notaris dapat dilakukan setelah memenuhi beberapa syarat sesuai Pasal 42 dan 43 UU Rumah Susun:

a. status hak kepemilikan atas tanah yang dijual,

b. kepemilikan IMB atas properti yang akan dibangun,

c. ketersediaan prasarana dalam lingkungan,

d. sarana, dan utilitas umum dalam lingkungan,

e. keterbangunan paling sedikit $20 \%$ dari keseluruhan rencana dibangun,

f. dan hal-hal lain yang diperjanjikan.

Apabila tidak terpenuhinya syarat PPJB yang telah diatur dalam UU Rumah Susun tersebut maka akibat hukumnya PPJB tersebut batal demi hukum. ${ }^{18}$ Syarat sahnya peralihan hak atas tanah melalui jual beli yaitu:

a. Pertama, syarat materiil meliputi pembeli berhak membeli, penjual berhak menjual, tanah yang diperjualbelikan tidak dalam sengketa.

b. Kedua, syarat formal meliputi semua syarat materiil yang sudah terlengkapi semua maka PPAT akan membuat akta jual belinya. ${ }^{19}$

Perjanjian pengikatan jual beli tanah dan properti selalui mendahuli sebelum perjanjian jual beli tanah dan propertinyadan dilakukan dihadapan PPAT (Pejabat Pembuat Akta Tanah) atau Notaris karena Akta Pengikatan Jual Beli menjadi sebuah akta otentik dengan kekuatan pembuktian yang sempurnadengan maksud untuk memberi perlindungan kepada para pihak yang membuat perjanjian. Untuk membatalkan sebuah perjanjian harus melalui putusan hakim melalui pengadilan seperti tercantum dalam Pasal 1266 ayat (2) KUHPerdata. Suatu perjanjian yang sah dapat dibatalkan dengan melihat apakah terdapat klausul yang mengatur tentang adanya kemungkinan pembatalan perjanjian disertai penyebab dan konsekuensi bagi para pihak. ${ }^{20}$

Penyerahan barang menurut Pasal 1475 KUHPerdata adalah penyerahan barang yang dijual kepada penguasaan pembeli dan menjadi kepunyaan pembeli,sedangkan ongkos terkait penyerahan tersebut menjadi tanggungan pembeli. Akan tetapi ongkos penyerahan tersebut dapat ditentukan sesuai kesepakan menurut

18 Lintang Yudhantaka. "Keabsahan Kontrak Jual Beli Rumah Susun Dengan Sistem Pre Project Selling". YURIDIKA. Volume 32 No. 1, Januari 2017

${ }^{19}$ Fredrik Mayore Saranaung. "Peralihan Hak Atas Tanah Menurut Peraturan Pemerintah Nomor 24 Tahun 1997." LEX CRIMEN Vol. VI/No. 1/Jan-Feb/2017

${ }^{20}$ Muh. Taufiq Amin. "Konsekuensi Pembatalan Akta Perjanjian Pengikatan Jual Beli (PPJB) Dalam Praktek Jual Beli Properti di Makassar". JURISPRUDENTIE Volume 5 Nomor 1 Juni 2018 
Pasal 1476 KUHPerdata, misalnya ongkos penyerahan ditanggung bersama atau ditanggung oleh penjual. ${ }^{21}$

Putusan Pengadilan Negeri Surabaya Nomor : 535/Pdt.G/2015/PN.SBY merupakan putusan yang sesuai dengan norma hukum serta mempertimbangkan keadilan sehingga asas kepastian hukum dan asas kemanfaatan yang yang dicitacitakan hukum benar-benar dapat dicapai.

Tinjauan dan analis penulis tersebut dapat dilihat pada pertimbangan hukum majelis hakim yang memeriksa dan memutus sengketa antara PT. Darmo Green Land dan Ronawati Wongso, diantaranya yaitu :

> Bahwa oleh karenanya ketentuan pasal 146 ayat (1) UU No.1 Tahun 2001 berlaku bagi perjanjian antara PT. Darmo Green Land dan Ronawati Wongso oleh karenanya perjanjian antara PT. Darmo Green Land dan Ronawati Wongso telah tidak memenuhi salah satu syarat sahnya perjanjian yakni suatu sebab yang halal dimana perjanjian tersebut dilarang oleh Undang-Undang, berdasarkan pertimbangan-pertimbangan tersebut di atas maka perjanjian jual beli tanah tersebut haruslah dinyatakan batal demi hukum;

> Bahwa PT. Darmo Green Land dan Ronawati Wongso telah menjalankan keawjiban masing-masing maka wajar jika keadaan dikembalikan seperti semua,dan PT. Darmo Green Land cukup adil dihukum mengembalikan semua pembayaran yang telah dilakukan Ronawati Wongso beserta bunga $1 \%$ dengan rincian :

- Pembayaran lunas Ronawati Wongso Rp. 3.300.000.000,-

- Pembebanan bunga sebesar 1\% x 25 Bulan = Rp. 825.000.000,-

Pengembalian Total PT. Darmo Green land ke Ronawati Wongso sebesar Rp. 4.125.000.000,-

Putusan Pengadilan Negeri Surabaya Nomor : 535/Pdt.G/2015/PN.SBY tersebut dinyatakan telah berkekuatan hukum tetap dengan keluarnya putusan Mahkamah Agung Nomor 1673 K/Pdt/2017 yang menolak permohonan kasasi Ronawati Wongso. ${ }^{22}$

\footnotetext{
${ }^{21}$ Made Gede Arthadana. "Akibat Hukum Pembatalan Akta Pengikatan Jual Beli Terhadap Biaya Yang Ditimbulkan Di Depan Notaris". KRETTHA DYATMIKA Vol 14 No 1 (2017)

22Putusan MAHKAMAH AGUNG Nomor 1673 K/Pdt/2017 Tahun 2017 RONAWATI WONGSO VS PT DARMO GREEN LAND
}

https://putusan.mahkamahagung.go.id/putusan/f25bd6f5acb4a0b9a8aa5628637106fc diakses 7 Desember 2019 pukul 23.56 


\section{PENUTUP}

\section{a. Kesmipulan}

Dalam Putusan Pengadilan Negeri surabaya Nomor : 535/Pdt.G/2015/PN.SBY. yang memutus sengketa jual beli tanah kavling antara PT. Darmo Green Land sebagai penjual dan Ronawati Wongso sebagai pembeli, yang mengabulkan sebagian gugatan PT. DARMO GREEN GARDEN yang memohon pembatalan Akta Ikatan Perjanjian Ikatan Jual Beli No. 33, yang dibuat dihadapan Notaris Wahyudi, SH di Surabaya pada tanggal 15 Februari ; Pertimbangan hukum yang digunakan oleh majelis hakim dalam pembatalan Akta Perjanjian Ikatan Jual Beli tanah kavling tersebut adalah karenan ketentuan pasal 146 ayat (1) UU No.1 Tahun 2001 berlaku bagi perjanjian antara PT. Darmo Green Land dan Ronawati Wongso oleh karenanya perjanjian antara PT. Darmo Green Land dan Ronawati Wongso telah tidak memenuhi salah satu syarat sahnya perjanjian yakni suatu sebab yang halal dimana perjanjian tersebut dilarang oleh Undang-Undang, berdasarkan pertimbangan tersebut di atas maka perjanjian ikatan jual beli tanah kavling tersebut haruslah dinyatakan batal demi hukum. Oleh karena kedua belah pihak telah memenuhi prestasinya maka keadaan haruslah dikembalikan kepada keadaan semula, yaitu PT. Darmo Green Land harus mengembalikan uang pembayaran tanah kavling dari Ronawati Wongso ditambah bungan sesuai kewajaran, mengenai bunga sebesar $1 \%$ yang seharusnya diberikan PT. Darmo Green Land kepada Ronawati Wongso menurut Majelis Hakim adalah cukup adil, bahwa dengan demikian PT. Darmo Green Land dihukum untuk mengembalikan uang pembayaran disertai dengan bunga dengan rincian:

$\checkmark$ Pengembalian uang pembelian Rp. 3.300.000.000,-

$\checkmark$ Bunga 1\% x 25 Bulan (Januari 2013 s/d Juni 2015) Rp. 825.000.000,-

$\checkmark$ Total Rp. 4.125.000.000,-

Putusan Pengadilan Negeri Surabaya Nomor : 535/Pdt.G/2015/PN.SBY yang Menyatakan Akta Perjanjian Ikatan Jual Beli No.33 tertanggal 15 Pebruari 2012 yang dibuat dihadapan Notaris Wahyudi, SH, di Surabaya batal demi hukum, tidak sah dan tidak memiliki kekuatan hukum mengikat telah sesuai dengan perundang-undangan yaitu batalnya perjanjian karena tidak terpenuhi syarat sahnya perjanjian tentang adanya sebab yang halal, sebagaimana diatur dalam pasal 1320 KUH Perdata.

\section{b. Saran}

Diktum hukum perlu mempelajari ilmu sosial jelas bukan pekerjaan sederhana. Sebab ahli hukum kebanyakan membaca pasal dan menghafalnya, kini ia harus berhadap-hadapan dengan buku teks dan laporan penelitian yang banyak melelahkan. Bisa jadi, justru orang hukum yang sosiologis mempelajari ilmu sosial untuk menutupi kelemahannya di aspek pemahaman dan penghafalannya terhadap pasal-pasal peraturan perundang-undangan. Melihat kasus dari sudut pandang holistik artinya memandang suatu kasus tersebut dari sudut pandang norma kaidah hukum, sosiologis, keadilan, manfaat, dan kepastian hukum. 


\section{DAFTAR PUSTAKA}

Fatmawati, dkk. (2019) "Kajian Yuridis Pembatalan Akta Pengikatan Jual Beli Tanah Terkait Syarat Subyektif', REPERTORIUM Vol 6, No 1

Fredrik Mayore Saranaung. (2017) "Peralihan Hak Atas Tanah Menurut Peraturan Pemerintah Nomor 24 Tahun 1997." LEX CRIMEN Vol. VI/No. 1

Isnantiana, Nur Iftitah. (2017) "Legal Reasoning Hakim dalam Pengambilan Putusan Perkara di Pengadilan". Islamadina: Jurnal Pemikiran Islam, [S.I.]

Lintang Yudhantaka. (2017) "Keabsahan Kontrak Jual Beli Rumah Susun Dengan Sistem Pre Project Selling". YURIDIKA. Volume 32 No. 1

Made Gede Arthadana. (2017) "Akibat Hukum Pembatalan Akta Pengikatan Jual Beli Terhadap Biaya Yang Ditimbulkan Di Depan Notaris". KRETTHA DYATMIKA Vol 14 No 1

Rafiq Adi Wardana, dkk. (2019) "Pembatalan Akta Jual Beli PPAT Yang Cacat Hukum Dengan Putusan Pengadilan (Studi Kasus Putusan Pengadilan Tinggi Tanjungkarang No. 17/Pdt.G/2012/PT. TK)". REPERTORIUM Vol 6, No 1

Akub, M.S., \& Badaru, B. (2012). Wawasan due process of law dalam sistem peradilan pidana. Yogyakarta: Rangkang Education.

Fanani, A.Z. (2013). Bersilsafat dalam putusan hakim (Teori dan praktik). Bandung: Mandar Maju.

Komisi Hukum Nasional Republik Indonesia. (2003) Laporan Akhir Rekrutmen Dan Karir Di Bidang Peradilan, Disusun Oleh Kelompok Kerja A.2 Fakultas Hukum Universitas Gadjah Mada, Yogjakarta: Fakultas Hukum UGM

Marwan, A. (2013). Satjipto Raharjo sebuah biografl intelektual \& pertarungan tafsir terhadap fllsafat hukum progresif. Yogyakarta: Thafa Media.

Mertokusumo, Soedikno. (2002) Hukum Acara Perdata Indonesia, Yogyakarta: Liberty

N.E. Algra, K. van Duyvendijk. (1983) terjemah J.C.T. Simorangkir. Mula Hukum, Beberapa Bab Mengenai Hukum dan Ilmu Hukum untuk Pendidikan Hukum dalam Pengantarullmu Hukum, Jakarta: Bina Cipta

Peter, Mahmud Marzuki. (2009) Pengantar Ilmu Hukum. Jakarta: Kencana

Prasetijo Rijadi dan Sri Priyati, (2017) Memahami Metode Penelitian Hukum Dalam Konteks Penulisan Skripsi/Tesis, Sidoarjo: Al Maktabah

Rifai, A. (2011). Penemuan hukum oleh hakim dalam perspektif hukum progresif. Cetakan Kedua. Jakarta: Sinar Grafika.

Rumokoy, D.A., \& Maramis, F. (2014). Pengantar ilmu hukum. Jakarta: PT Raja Grafindo. 
Sidharta. (2000) Penalaran Hukum dalam Sudut Pandang Keluarga Sistem Hukum dan Penstudi Hukum, Bandung: Citra Aditya Bakti

Sujono, A.R., \& Daniel, B. (2013). Komentar dan pembahasan Undang-Undang Nomor 35 Tahun 2009 tentang narkotika. Jakarta: Sinar Grafika.

Tim Peneliti Komisi Yudisial RI. (2009). Profesionalisme Hakim: Studi Tentang Putusan Pengadilan Tingkat Pertama dalam Perkara Perdata dan Pidana di Indonesia. Jakarta, Riset: Komisi Yudisial

Voll, W.D.S. (2013). Negara hukum dalam keadaan pengecualian. Jakarta: Sinar Grafika.

\section{Undang - Undang :}

Kitab Undang - Undang Hukum Perdata

UU No. 48 Tahun 2009 Tentang Kekuasaan Kehakiman

UU No. 1 Tahun 2011 Tentang Perumahan dan Kawasan Pemukiman

\section{World Wide Web :}

Putusan PN SURABAYA Nomor 535/Pdt.G/2015/PN.SBY Tahun 2015 PT. DARMO GREEN LAND melawan RONAWATI WONGSO https://putusan.mahkamahagung.go.id/putusan/4e1 bbc949e38ac3f79593977c5 $\underline{794882}$ diakses 7 Desember 2019 pukul 23.46

Putusan MAHKAMAH AGUNG Nomor 1673 K/Pdt/2017 Tahun 2017 RONAWATI WONGSO VS PT DARMO GREEN LAND

https://putusan.mahkamahagung.go.id/putusan/f25bd6f5acb4a0b9a8aa5628637106f c diakses 7 Desember 2019 pukul 23.56 